\title{
Pre-emergence herbicides affect seedling emergence of tropical forest tree species
}

\author{
Diego Cerveira de Souza ${ }^{1} \cdot$ Vera Lex Engel ${ }^{1}$
}

Received: 18 December 2015/Accepted: 5 August 2016/Published online: 28 November 2016

(C) Northeast Forestry University and Springer-Verlag Berlin Heidelberg 2016

\begin{abstract}
Testing techniques to reduce weed infestation is a crucial step in developing direct tree seeding systems. The use of pre-emergence herbicides may be an alternative to manual weeding techniques, but so far, information on how they affect the seeds of native tree species is scarce. We established a greenhouse experiment to evaluate the effects of four preemergence herbicides (atrazine, diuron, isoxaflutole and oxyfluorfen) on weed suppression and seedling emergence and early growth of seven tropical forest tree species (Annona coriacea Mart., Citharexylum myrianthum Cham., Cordia ecalyculata Vell., Peltophorum dubium (Spreng.) Taub., Psidium guajava L., Pterogyne nitens Tul. and Schinus terebinthifolia Raddi). The experimental design was a randomized complete block design with five treatments and five replicates. The treatments consisted of a single dose of each pre-emergence herbicide and a control. Throughout the 60 days after sowing we evaluated weed cover and seedling emergence and early growth of tree species. Overall, our results suggest that all tested herbicides reduced weed cover; however, they also negatively affected tree species seedling
\end{abstract}

Project funding: The first author was financially supported by a Scientific Initiation Scholarship from FAPESP (São Paulo Research Council) and the second author was financially supported by a Research Productivity Fellowship from CNPq (National Council for Research and Technological Development).

The online version is available at http://www.springerlink.com

Corresponding editor: Zhu Hong

Diego Cerveira de Souza

diegocerveira@hotmail.com

1 Forest Science Department, Agronomic Sciences CollegeFCA, São Paulo State University - UNESP, P.O. Box 237, Botucatu, SP 18603-970, Brazil emergence. Of the four herbicides tested, atrazine and diuron showed the greatest effects on tree seedling emergence, oxyfluorfen was least aggressive towards native species and isoxaflutole was most effective in weed control. Native tree species varied in their responses to herbicides, indicating that future experiments should increase the number of species tested as well as investigate how seed traits can affect the species responses to different herbicides.

Keywords Pre-emergence herbicides - Weed control · Direct seeding $\cdot$ Seedling emergence $\cdot$ Tropical seasonal forests

\section{Introduction}

Large parts of the world's tropical forests have been deforested and degraded over the last few centuries (Lamb 1998; Holl 1999), calling for urgent intervention aiming at restoring biodiversity, ecological functioning and ecosystem services provided by tropical forests (Mittermeier et al. 2004; Lamb et al. 2005). Natural forest regeneration (passive restoration or autogenic regrowth) can be a suitable pathway to restore degraded tropical landscapes (Parrotta et al. 1997). However, in cases where frequent and severe disturbances (e.g. prolonged grazing and fire) have radically reduced the resilience of these areas and impeded forest regeneration, employing artificial regeneration techniques might be a better option to achieve restoration success (Rodrigues et al. 2009; Ferreira and Santos 2012).

Most forest restoration techniques involve planting nursery-raised seedlings, especially in tropical areas; however, this option is often too costly to be used in large areas (Lamb et al. 2005; Chazdon 2008; Rodrigues et al. 2011). In contrast, direct seeding (sowing seeds directly 
into deforested areas) may be an alternative way of restoring deforested tropical landscapes at low cost and with minimal labour intensity (Engel and Parrotta 2001; Tunjai and Elliott 2012; Hossain et al. 2014).

Although many studies have demonstrated the effectiveness of direct seeding techniques (Engel and Parrotta 2001; Camargo et al. 2002; Bonilla-Moheno and Holl 2010), several biotic and abiotic factors constrain its applicability (Jinks et al. 2006; Cole et al. 2011; Tunjai and Elliot 2012). One of the main factors is weed competition (Doust et al. 2006; 2008; Douglas et al. 2007), which reduces seedling establishment and growth (Sun and Dickson 1996; Dodd and Power 2007; Pereira et al. 2013). This is especially problematic in the first year after sowing, when seedlings have very small root systems (Willoughby et al. 2003). Moreover, weeds often build up a viable soil seed bank, making initial management of restored sites very difficult and challenging (D'Antonio and Meyerson 2002).

To date, both manual (using mattocks or weed-whackers) and chemical (post-emergence herbicide application) weeding techniques show low efficiency and are likely to damage emerging seedlings; besides, they are costly and are therefore restricted to small areas (Durigan et al. 2013). Hence, studies are needed to develop techniques to control weed competition in order to improve survival and early growth of direct-seeded tree species (Sun and Dickson 1996).

Using pre-emergence herbicides prior to sowing of tree species may be a feasible option to improve direct seeding systems. It can reduce or eliminate weed seed banks and therefore decrease competition by weeds (Willoughby et al. 2004; Jinks et al. 2006). Most commercial brands of preemergence herbicides are not selective for grasses, but affect a wide range of herbaceous plants (Andrei 2013). Therefore, it is essential to first identify effective pre-emergence herbicides which are not harmful to tree species used in restoration. Although pre-emergence herbicide effects have been tested in a few studies in temperate areas (Willoughby et al. 2003, 2006), there is no information about how they may affect the seedling emergence and early growth of tropical forest tree species. This lack of information inhibits the use of pre-emergence herbicides in the tropics.

We investigated the effects of four pre-emergence herbicides on seedling emergence and early performance of selected tree species. Moreover, we tested the effectiveness of the same herbicides in providing satisfactory weed control by reducing or eliminating weed seed banks present in abandoned fields. The aim of our study was to find the most suitable pre-emergence herbicide for effective weed control without compromising on seedling emergence and early growth of native tree species.

\section{Materials and methods}

Our experiment took place in the tree nursery of the Agronomic Sciences College at Botucatu, SP, Brazil $\left(22^{\circ} 51^{\prime} 22^{\prime \prime} \mathrm{S} 48^{\circ} 26^{\prime} 01^{\prime \prime} \mathrm{W}\right)$, in April 2010. We adopted a randomized complete block design (RCBD) with five treatments and five replicates. The treatments consisted of a single dose of four pre-emergence herbicides and a control, which was not treated (Table 1). Herbicides were selected from the range of formulations recommended for the soil types and common weeds in the study area, and were applied following the recommendations of the manufacturers.

Each experimental plot consisted of a plastic tray (100 cm long, $30 \mathrm{~cm}$ wide and $15 \mathrm{~cm}$ deep) filled to a depth of $10 \mathrm{~cm}$ with moist topsoil collected at a depth of $0-10 \mathrm{~cm}$ (A horizon) in an abandoned field dominated by invasive exotic grasses, mainly Urochloa decumbens (Stapf.) Webster and Panicum maximum Jacq. (Poaceae). The soil was a moderately acidic and leached sandy Oxisol of very low fertility.

We selected seven native tree species based on seed availability and on their ecophysiological and silvicultural characteristics, representing a functionally diverse sample of regional tropical seasonal forests. The species used were Annona coriacea Mart., Citharexylum myrianthum Cham., Cordia ecalyculata Vell., Peltophorum dubium (Spreng.) Taub., Psidium guajava L., Pterogyne nitens Tul. and Schinus terebinthifolia Raddi. Seeds were collected during the last month prior to sowing, either from the ground or the crown, depending on the species. After collection, seeds were removed from pods and stored in a cold chamber until sowing. Pre-germination treatments (mechanical scarification) were carried out for two species, according to the literature recommendations: $P$. dubium (Bianchetti and Ramos 1981) and P. nitens (Nassif and Perez 1997).

We sowed twenty seeds of each species per experimental plot. Immediately after sowing, pre-emergence herbicides were sprayed using a laboratory track sprayer and the trays were then watered twice a day by an automatic sprinkler system and exposed to full sunlight. The sowing depth was approximately 5-20 mm depending on seed size (larger seeds had more soil coverage than smaller ones).

Weed coverage, seedling emergence and early growth were monitored for 60 days after sowing; no emergence was recorded after that. Weed coverage was evaluated 45 and 60 days after sowing (to the nearest \%) by a visual percentage scale varying from $0 \%$ (no weed cover) to $100 \%$ (fully covered tray). Seedling emergence (percentage of live seedlings per number of seeds sown) was recorded 
Table 1 Pre-emergence herbicide details

\begin{tabular}{llll}
\hline Active ingredient & Commercial product & Mechanism of action & Application rate \\
\hline Atrazine & Gesaprim 500 Ciba-Geisy & Photosynthesis inhibitor & $4 \mathrm{l} \mathrm{ha}^{-1}$ \\
Diuron & Diuron 500 SC Milenia & Photosynthesis inhibitor & $41 \mathrm{ha}^{-1}$ \\
Isoxaflutole & Fordor 750 WG & Carotenoid biosynthesis inhibitor & $75 \mathrm{~g} \mathrm{ha}^{-1} \mathrm{ai}$ \\
Oxyfluorfen & Goal BR & Photosynthesis inhibitor & $720 \mathrm{~g} \mathrm{ha}^{-1} \mathrm{ai}$ \\
\hline
\end{tabular}

ai active ingredient at 45 and 60 days post-sowing. Early seedling growth (stem height from ground level to the tip of the terminal axis) was recorded 60 days after sowing.

Analysis of variance (ANOVA) and Tukeýs HSD test were used to test the effects of pre-emergence herbicides on weed infestation, seedling emergence and early growth for each species at $p=0.05$. Prior to analysis, categorical variables expressed as a percentage (weed coverage and seedling emergence) were arcsine-square-root transformed to meet the assumptions of normality and homogeneity of variances. All statistical tests were performed using the Assistat 7.5 Beta Software package (Universidade Federal de Campina Grande, Brazil). Species that did not germinate at all were excluded from data analysis.

\section{Results}

\section{Effects of pre-emergence herbicides on seedling emergence}

A. coriacea and $C$. ecalyculata both failed to germinate under experimental conditions and were therefore excluded from data analysis. Seedling emergence started about 15 days after sowing; no emergence was observed after 60 days.

All tested herbicides significantly affected seedling emergence after 45 and 60 days, but species showed contrasting responses to different herbicides. Unlike seedling emergence, early seedling growth did not differ significantly among treated and control plants or among different herbicide types. Emergence rates of control seeds were significantly higher than the rates of treated seeds (Table 2), at 45 and 60 days after sowing. Among the different herbicides, atrazine and diuron had the strongest negative effects on seedling emergence. Atrazine reduced average emergence by $40.8 \%$ (45 days) and $41.4 \%$ (60 days), while diuron decreased emergence by 37.1 and $37.8 \%$, respectively. In contrast, oxyfluorfen showed the lowest negative impact on seedling emergence, decreasing average emergence by only $21.8 \%$ (45 days) and $22.4 \%$ (60 days) in comparison to control (Table 2).

Although all herbicides reduced seedling emergence rates, the effects varied significantly among species (Fig. 1). Emergence of C. myrianthum and S. terebinthifolia was not significantly affected by any treatment after 45 and 60 days. However, application of all herbicides significantly reduced emergence of $P$. dubium up to $100 \%$ after 45 and 60 days compared to control plots.

Atrazine and diuron significantly reduced emergence of $P$. guajava until 45 days after sowing, but only diuron still had a negative effect after 60 days. Unexpectedly, $P$. guajava plots treated with isoxaflutole and oxyfluorfen showed even higher seedling emergence rates than control plots with $P$. guajava. Emergence of $P$. nitens was significantly negatively affected in both evaluations by most herbicides except oxyfluorfen.

\section{Efficacy of pre-emergence herbicides}

All tested herbicides were effective in controlling weed species from the soil seed bank at 45 and 60 days after sowing (Table 2). The main weed species in our experimental plots were invasive exotic grasses, mainly $U$.
Table 2 Effect of pre-emergent herbicides on native tree species seedling emergence, seedling height and weed cover (mean $\pm \mathrm{SE}$ )

\begin{tabular}{|c|c|c|c|c|}
\hline \multirow[t]{2}{*}{ Herbicide } & \multicolumn{2}{|c|}{ Emergence $(\%)^{*}$} & \multirow{2}{*}{$\begin{array}{l}\text { Height }(\mathrm{cm})^{*} \\
60 \text { days }\end{array}$} & \multirow{2}{*}{$\begin{array}{l}\text { Weed cover }(\%)^{*} \\
45 \text { days }\end{array}$} \\
\hline & 45 days & 60 days & & \\
\hline Control & $55.6(5.0) \mathrm{a}$ & $55.3(6.1) \mathrm{a}$ & $4.3(1.2) \mathrm{a}$ & $76.0(8.9) \mathrm{a}$ \\
\hline Atrazine & $32.9(2.7) \mathrm{c}$ & $32.4(2.9) \mathrm{d}$ & $4.2(1.5) \mathrm{a}$ & $17.0(21.1) \mathrm{b}$ \\
\hline Diuron & $35.0(3.7) \mathrm{c}$ & $34.4(3.7) \mathrm{cd}$ & $5.0(1.6) \mathrm{a}$ & $2.0(4.5) \mathrm{b}$ \\
\hline Isoxaflutole & $39.4(4.8) \mathrm{bc}$ & $40.3(3.8) \mathrm{bc}$ & $4.6(1.3) \mathrm{a}$ & $0.0(0.0) \mathrm{b}$ \\
\hline Oxyfluorfen & $43.5(2.7) b$ & $42.9(2.8) \mathrm{b}$ & $5.8(2.2) \mathrm{a}$ & $4.0(5.5) b$ \\
\hline
\end{tabular}

* Different letters in the same column indicate significantly different means (mean differentiation using Tukey's HSD at $p=0.05$ ) 

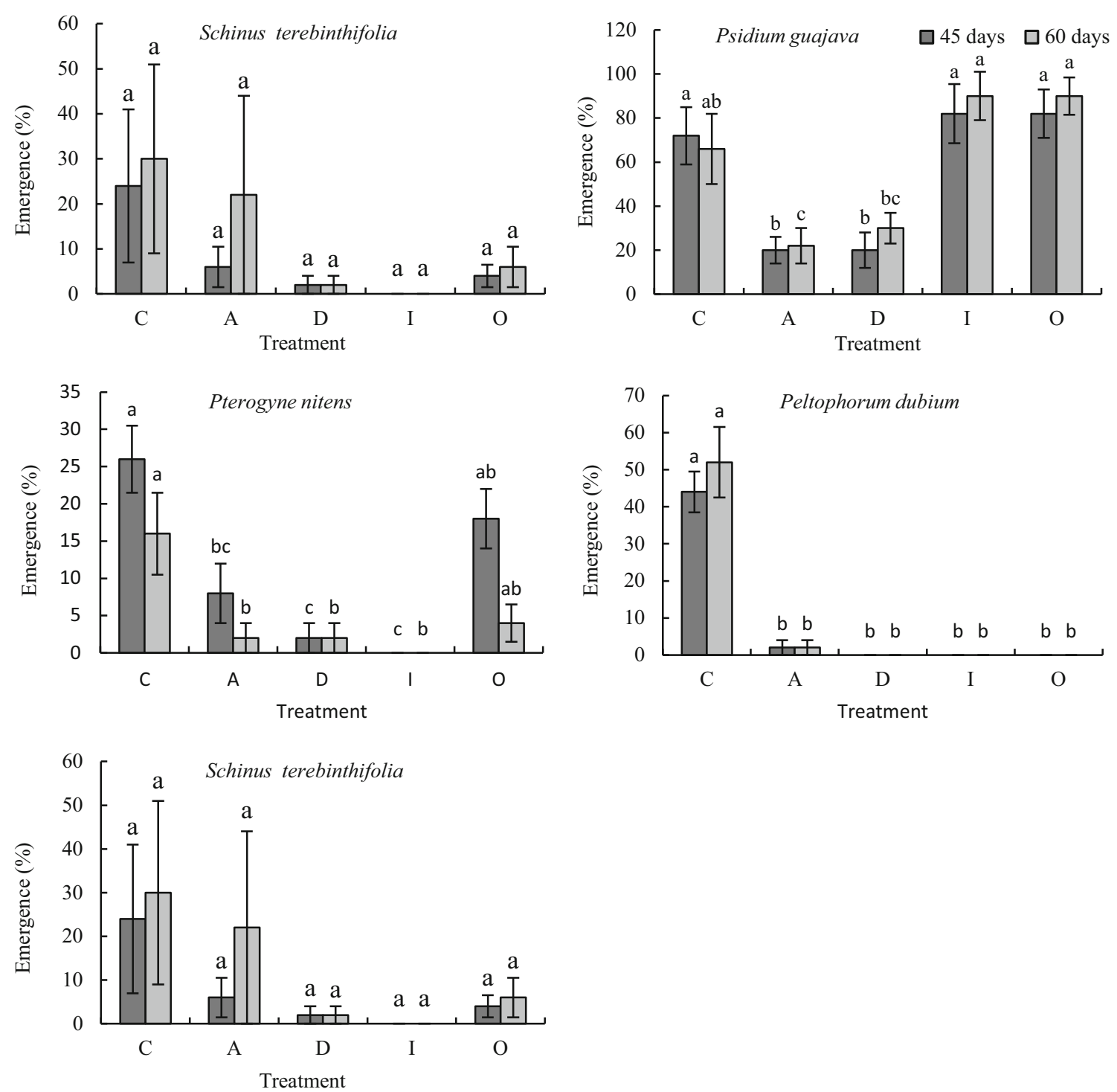

Fig. 1 Mean seedling emergence $(\%)$ of species tested in each of five treatments ( $C$ colntrol, $A$ atrazine, $D$ diuron, $I$ isoxaflutole, $O$ oxyfluorfen). Errors bars are mean \pm SE. Means with the same letter were similar among treatments per Tukey's HSD $(p=0.05)$

decumbens and P. maximum. Primarily, isoxaflutole was the most effective herbicide for weed control, reducing weed cover by up to $100 \%$ as compared to control plots in both evaluations. In contrast, atrazine was least effective, reducing weed cover by only $70 \%$.

\section{Discussion}

\section{Effects of pre-emergence herbicides on seedling emergence}

Our results suggest that using pre-emergence herbicides for weed control in direct seeding systems to restore tropical forests poses a considerable risk for native tree species.
Overall, all tested herbicides suppressed seedling emergence of native tree species. However, the degree of suppression varied by species and herbicide type. While $C$. myrianthum showed some tolerance to atrazine and oxyfluorfen, $P$. guajava was tolerant to isoxaflutole and oxyfluorfen, which in this case even increased seedling emergence rates compared to control plots. In contrast, $P$. nitens, $P$. dubium and S. terebinthifolia showed no tolerance to any tested herbicide.

Our results highlight the need to test a larger tree species pool with different seed traits (e.g. size, shape, coat thickness or moisture content) to detect general response patterns to pre-emergence herbicides. Willoughby et al. (2003), who tested the effects of nine pre-emergence herbicides on seedling emergence and early growth of 14 
broadleaved species used in direct seeding experiments to create new woodlands in the UK, reported similar results. Their study indicated that only two out of nine herbicides (pendimethalin and napropamide) were suitable for use with most species tested, in particular Fraxinus excelsior and Acer pseudoplatanus. The authors also emphasized the need for further field trials before adopting pre-emergence herbicides in large areas restored by direct seeding.

In our study, the species most tolerant to pre-emergence herbicides was $P$. guajava, an invasive plant in many tropical and subtropical countries (Ellshoff et al. 1995). Invasive plants have several specific traits, including nonspecialized germination requirements (Lake and Leishman 2004). This higher germination potential under adverse conditions may enhance the tolerance to pre-emergence herbicides in $P$. guajava seeds.

None of our four pre-emergence herbicides affected the early growth of emerged seedlings. This can be explained by the fact that during the initial phases of establishment, seedlings rely on the cotyledon reserves and do not take up nutrients from the soil (Leishman et al. 2001), thereby reducing the uptake of pre-emergence herbicides. However, such results must be interpreted carefully and future studies should evaluate longer growth periods (after abscission of the cotyledons) in order to detect possible residual effects of pre-emergence herbicides on seedling growth.

\section{Effectiveness of pre-emergence herbicides in weed control}

The main weed species found in abandoned crop fields and pastures in our study region were African grasses ( $U$. decumbens and $P$. maximum). These were introduced centuries ago as forage plants for cattle, but have become invasive and are now dominating open habitats such as natural grasslands and savannas; they have also become aggressive invaders in several deforested ecosystems in Brazil (Pivello et al. 1999). Exotic grasses show high potential for invasion as they readily disperse, compete with native plants for nutrients and water, and are able to severely modify the environment (D'Antonio and Vitousek 1992). Moreover, exotic species are often the first species to recolonise disturbed and degraded areas, even if they were not present in the pre-disturbance community (D'Antonio and Meyerson 2002).

Exotic grasses spreading in tropical regions create a physical barrier that absorbs or intercepts incident light at the soil surface, thereby preventing germination of seeds present in the soil seed bank (Hughes and Vitousek 1993). Similar effects are expected for seeds directly sown in disturbed or degraded areas. Several studies have shown that the surrounding vegetation, especially native and exotic grasses, can inhibit the growth and survival of seedlings established by direct seeding (Doust et al. 2006, 2008; Pereira et al. 2013). However, reducing weed competition in large-scale restoration programs is a challenging task (Doren et al. 2009).

Our results are promising as they show that all tested pre-emergence herbicides were effective at reducing or eliminating weed species emerging from the soil seed banks. Therefore, the use of pre-emergence herbicides may be a suitable option in restoring degraded areas.

All tested herbicides reduced weed cover; however, isoxaflutole was most effective and reduced weed cover by up to $100 \%$. Although it has been tested in croplands, there is no research on the use of isoxaflutole in restoration areas. Spader and Vidal (2000) tested five pre-emergence herbicides in corn croplands dominated by Urochloa sp. and reported that isoxaflutole was the most effective. However, considering the trade-off between efficacy of weed control and suppression of native tree species seedling emergence, and based on our study results, we recommend the use of oxyfluorfen instead of isoxaflutole.

In our study, we applied pre-emergence herbicides immediately after the sowing of seeds. In order to reduce negative effects on native tree seeds, future studies should test the residence time of each herbicide in the soil, thereby determining a minimum gap time between herbicide spraying and tree species sowing. Moreover, future experiments should test the application of pre-emergence herbicides several months after the sowing of native tree species. We observed no seedling emergence after 60 days of sowing; therefore, herbicide spraying after this period might reduce weed infestation without affecting native tree seedling emergence.

\section{Conclusions}

The use of pre-emergence herbicides for weed control in direct seeding systems to restore tropical seasonal forests is not recommended. Our study indicates that although preemergence herbicides can effectively reduce or even eliminate weed seed banks in tropical regions, they also negatively affect seedling emergence of most tree seeds used in restoration. However, the effects of pre-emergence herbicides on tree seedling emergence varied greatly among the different species. Overall, oxyfluorfen was least aggressive towards seeds of native tree species and isoxaflutole was most effective in the reduction of weed cover.

Further greenhouse and field experiments are needed to test a larger species pool and more pre-emergence herbicides, as well as the possible influence of different seed traits on their responses to herbicide application. Trials on soil residence-time of each pre-emergence herbicide type 
will help to establish a minimum time gap between herbicide spraying and seed sowing in order to minimize any negative effects.

Acknowledgements The authors would like to thank staff and students from the Laboratory of Forest Ecology and Restoration-LERF (Forest Science Department, Agronomic Sciences College-FCA), especially E. C. Mattos, who provided valuable assistance during trial installation and data collection.

\section{References}

Andrei E (2013) Compêndio de defensivos agrícolas: guia prático de produtos fitossanitários para uso agrícola (9nd edition). Organização Andrei, São Paulo, pp 1577-1602

Bianchetti A, Ramos A (1981) Quebra de dormência de sementes de canafístula Peltophorum dubium (Spreng.) Taubert: resultados preliminares. Bol Pesqui Florest 3:77-86

Bonilla-Moheno M, Holl KD (2010) Direct seeding to restore tropical mature-forest species in areas of slash-and-burn agriculture. Restor Ecol 18(2):438-445

Camargo JLC, Ferraz IDK, Imakawa AM (2002) Rehabilitation of degraded areas of Central Amazonia using direct sowing of forest tree seeds. Restor Ecol 10(4):636-644

Chazdon RL (2008) Beyond deforestation: restoring forests and ecosystem services on degraded lands. Science 320(5882): $1458-1460$

Cole RJ, Holl KD, Keene CL, Zaha RA (2011) Direct seeding of latesuccessional trees to restore tropical montane forest. For Ecol Manag 261(10):1590-1597

D'Antonio C, Meyerson LA (2002) Exotic plants species as problems and solutions in ecological restoration: a synthesis. Restor Ecol 10(4):703-713

D'Antonio CM, Vitousek PM (1992) Biological invasion by exotic grasses, the grass/fire cycle, and global change. Annu Rev Ecol Syst 23:63-87

Dodd MB, Power IL (2007) Direct seeding of indigenous tree and shrub species into New Zealand hill country pasture. Ecol Manag Restor 8(1):49-55

Doren RF, Volin JC, Richards JH (2009) Invasive exotic plant indicators for ecosystem restoration: an example from the Everglades restoration program. Ecol Ind 9(6):S29-S36

Douglas GB, Dodd MB, Power IL (2007) Potential of direct seeding for establishment native plants into pastoral land in New Zealand. N Z J Ecol 31(2):143-153

Doust SJ, Erskine PD, Lamb D (2006) Direct seeding to restore rainforest species: microsite effects on the early establishment and growth of rainforest tree seedlings on degraded land in the wet tropics of Australia. For Ecol Manag 234(1):333-343

Doust SJ, Erskine PD, Lamb D (2008) Restoring rainforest species by direct seeding: tree seedling establishment and growth performance on degraded land in the wet tropics of Australia. For Ecol Manag 256(5):1178-1188

Durigan G, Guerin N, Da Costa JNMN (2013) Ecological restoration of Xingu Basin headwaters: motivations, engagement, challenges and perspectives. Philos Trans R Soc B 368(1619):2-9

Ellshoff ZE, Gardner DE, Wikler C, Smith CW (1995) Annotated bibliography of the genus Psidium, with emphasis on $P$. cattleianum (strawberry guava) and $P$. guajava (common guava), forest weeds in Hawai'i. Honolulu: Cooperative National Park Resources Studies Unit. Tech Rep 95:1-5

Engel VL, Parrotta JA (2001) An evaluation of direct seeding for restoration of degraded lands in central São Paulo state, Brazil. For Ecol Manag 152(1):169-181
Ferreira RA, Santos PL (2012) Direct sowing: an alternative to the restoration of ecosystems of tropical forests. In: Sudarshana P, Nageswara-Rao M, Soneji JR (eds) Tropical forests. InTechOpen, Rijeka, pp 333-348

Holl KD (1999) Factors limiting tropical rain forest regeneration in abandoned pasture: seed rain, seed germination microclimate, and soil. Biotropica 31(2):229-242

Hossain F, Elliott S, Chairuangsri S (2014) Effectiveness of direct seeding for forest restoration on severely degraded land in Lampang Province, Thailand. Open J For 4(5):512-519

Hughes F, Vitousek PM (1993) Barriers to shrub reestablishment following fire in the seasonal submontane zone of Hawaíi. Oecologia 93(4):557-563

Jinks RL, Willoughby I, Baker C (2006) Direct seeding of ash (Fraxinus excelsior L.) and sycamore (Acer pseudoplatanus L.): the effects of sowing date, pre-emergent herbicides, cultivation, and protection on seedling emergence and survival. For Ecol Manag 237(1):373-386

Lake JC, Leishman MR (2004) Invasion success of exotic plants in natural ecosystems: the role of disturbance, plant attributes and freedom from herbivores. Biol Conserv 117(2):215-226

Lamb D (1998) Large-scale ecological restoration of degraded tropical forest lands: the potential role of timber plantations. Restor Ecol 6(3):271-279

Lamb D, Erskine PD, Parrotta JA (2005) Restoration of degraded tropical forest landscapes. Science 310(5754):1628-1632

Leishman MR, Wright IJ, Moles AT, Westoby M (2001) The evolutionary ecology of seed size. In: Fenner M (ed) Seeds: the ecology of regeneration in plant communities. CAB International, Wallingford, pp 31-57

Mittermeier RA, Gil P, Hoffmann M, Pilgrim J, Brooks T, Mittermeier CG, Lamoreux J, Da Fonseca GAB (2004) Hotspots revisited: earth's biologically richest and most endangered terrestrial ecoregions. CEMEX, Conservation International and Agrupacio'n Sierra Madre, Monterrey, p 390

Nassif SML, Perez SCJGA (1997) Germinação de sementes de amendoim-do-campo (Pterogyne nitens Tul.): influência dos tratamentos para superar a dormência e profundidade de semeadura. Rev Bras Sementes 19(2):171-178

Parrotta JA, Turnbull JW, Jones N (1997) Catalyzing native forest regeneration on degraded tropical lands. For Ecol Manag 99(1-2):1-7

Pereira SR, Laura VA, Souza ALT (2013) Establishment of Fabaceae tree species in a tropical pasture: influence of seed sizes and weeding methods. Restor Ecol 21(1):67-74

Pivello VR, Shida CN, Meirelles ST (1999) Alien grasses in Brazilian savannas: a threat to the biodiversity. Biodivers Conserv 8(9):1281-1294

Rodrigues RR, Lima RAF, Gandolfi S, Nave AG (2009) On the restoration of high diversity forests: 30 years of experience in the Brazilian Atlantic Forest. Biol Conserv 142(6): 1242-1251

Rodrigues RR, Gandolfi S, Nave AG, Aronson J, Barreto TE, Vidal CY, Brancalion PHS (2011) Large-scale ecological restoration of high-diversity tropical forests in SE Brazil. For Ecol Manag 261(10):1605-1613

Spader V, Vidal RA (2000) Eficácia de herbicidas graminicidas aplicados em pré-emergência no sistema de semeadura direta do milho. Planta Daninha 18(2):373-380

Sun D, Dickson GR (1996) The competition effect of Brachiaria decumbens on the early growth of direct-seeded trees of Alphitonia petriei in Tropical North Australia. Biotropica 28(2):272-276

Tunjai P, Elliott S (2012) Effects of seed traits on the success of direct seeding for restoring southern Thailand's lowland evergreen forest ecosystem. N For 43(3):319-333 
Willoughby I, Clay D, Dixon F (2003) The effect of pre-emergence herbicides on germination and early growth of broadleaved species used for direct seeding. Forestry 76(1):83-94

Willoughby I, Jinks RL, Kerr G, Gosling PG (2004) Factors affecting the success of direct seeding for lowland afforestation in the UK. Forestry 77(5):467-482
Willoughby I, Jinks RL, Stokes V (2006) The tolerance of newly emerged broadleaved tree seedlings to the herbicides clopyralid, cycloxydim and metazachlor. Forestry 79(5):599-608 